\title{
Trace elements and cell-mediated immunity in gestational and pre-gestational diabetes mellitus at third trimester of pregnancy
}

\author{
Fadia Mahmoud ${ }^{1}$, Habib Abul ${ }^{2}$, Ali Dashti ${ }^{1}$, Waleed Al-Jassar ${ }^{3}$, Alexander Omu ${ }^{3}$
}

${ }^{1}$ Department of Medical Laboratory Sciences, Faculty of Allied Health Sciences Kuwait

Departments of ${ }^{2}$ Pharmacology and ${ }^{3}$ Obstetrics \& Gynaecology, Faculty of Medicine, Kuwait University, Kuwait

Corresponding author: Fadia Fouad Mahmoud Department of Medical Laboratory Sciences

Faculty of Allied Health Sciences Kuwait University

B.O. Box 31470- Sulaibekhat

Kuwait 90805

fadia@hsc.edu.kw

Tel.: 00965 999-66-154

Fax.: 00965 249-838-35

Received: 26 September 2012

Accepted: 16 November 2012

Copyright (C) 2012 by

Academy of Sciences and Arts

of Bosnia and Herzegovina.

E-mail for permission to publish:

amabih@anubih.ba

\begin{abstract}
Objective. The aim of the study: To evaluate the correlations between $\mathrm{Zn} 2+, \mathrm{Cu} 2+, \mathrm{Mg} 2+, \mathrm{Se} 2+$ and $\mathrm{Cr} 3+$ and alteration in $\mathrm{T}$ cell subsets during diabetic and normal pregnancy. Methods. The study involved 63 women with gestational diabetes mellitus (GD) and 16 pregnant women with Type 2 diabetes and 48 healthy, non-pregnant women were included as controls. Ten $\mathrm{ml}$ of whole venous blood from each participant was analyzed for electrolytes by atomic absorption; total antioxidant activity, individual enzymatic antioxidants by spectrophotometry; and lymphocyte sub-populations by flow cytometry. Results. There were significant changes in lymphocyte sub-populations: $\mathrm{Na}$ ive $\mathrm{T}$ cells were decreased and memory T-cells and activated $\mathrm{T}$ cells (CD4+HLA-DR+, CD4+CD29+) were increased in diabetes in pregnancy. $\mathrm{Zn} 2+$ and $\mathrm{Cr} 3+$ deficiency were observed in Type 2 diabetics with an increase in $\mathrm{Cu} 2+$ in all pregnant cohorts. In healthy pregnant subjects, CD4+-HLA-DR+ was increased in direct proportion to serum $\mathrm{Mg} 2+(\mathrm{p}<0.05)$ and $\mathrm{Se} 2+(\mathrm{p}<0.01)$. In insulin-treated GD patients, CD4+CD29+ cells were increased proportionally to serum $\mathrm{Zn} 2+$ $(\mathrm{p}<0.05)$ while in diet controlled GD cohort CD45RO+/ CD45RA+ T cells correlated directly with serum $\mathrm{Mg}(\mathrm{p}<0.05)$ and $\mathrm{Zn} 2+(\mathrm{p}<0.01)$ while it correlated inversely with serum $\mathrm{Cu} 2+(\mathrm{p}<0.01)$. Conclusions. The results of the present study show a correlation between trace element deficiency and increased lipid peroxidation in diabetes in pregnancy and lymphocyte activation. Dietary manipulation may, therefore, point to improvement in existing approaches to management of diabetes mellitus in pregnancy.
\end{abstract}

Key words: Gestational diabetes, Lymphocyte activation, Trace elements.

\section{Introduction}

In approximately $3 \%$ of pregnancies, there is diminished insulin secretion, with varying degrees of insulin resistance and diabetes in pregnancy (1-4). Gestational diabetes melli- tus (GDM) is carbohydrate intolerance that begins or is first recognized during pregnancy (5). This could be newly diagnosed type 1, type 2 Diabetes Mellitus or secondary to metabolic changes related to pregnancy (6). In GDM, there is enhanced ability of glu- 
cose to cross the placenta, with resultant fetal hyperglycaemia, hyperinsulinaemia and macrosomia. This may lead to a variety of fetal pathologies postpartum and pregnancyassociated morbidity, such as preeclampsia (79) and susceptibility to development of GD in subsequent pregnancies. Up to $90 \%$ of GDMafflicted women develop type 2 diabetes (10). GDM may therefore, serve to unmask women who are predisposed and destined to develop type 2 diabetes later in life (11).

The pathogenic effect of high glucose in concert with fatty acids is mediated via increased production of reactive oxygen species (ROS) and reactive nitrogen species (RNS). These free radicals directly induce tissue damage by activating a number of cellular stress sensitive pathways, such as nuclear factor kB (NF-kB), p38 mitogen-activated protein kinase and $\mathrm{NH}_{2}$-terminal jun kinase/stress-activated protein kinase (12). There is abundant evidence linking oxidative stress to insulin resistance (13). Oxidative stress has long been associated with the etiology of late complications of diabetes mellitus (14). Both insulin resistance and decreased insulin secretion are major features of the pathophysiology of Type 2 Diabetes mellitus (15) and GDM. Early diagnosis of gestational diabetes minimizes the exposure of the developing fetus to suboptimal conditions and prevents perinatal complications and their sequelae (15).

There are increased percentages of HLA$\mathrm{DR}+$ and CD56+ activated T-cells during the first trimester (16), increased soluble interleukin-2 receptor (sIL-2R) and CD8+ T cell levels (17) and maternal serum factors which down regulate $B$ cell activity (18). Decreased absolute numbers of circulating $\mathrm{T}$ helper and NK cells late in pregnancy have also been suggested to play a role in maintenance of healthy gestation (19).

Iron, zinc, selenium and copper are necessary for the activity of the enzymes that neutralize free radicals, in the form of super- oxide dismutase, catalase and glutathione peroxidase (20). Zinc deficiency is associated with increased plasma glucocorticord levels, which induces apoptotic loss of precursor and immature G-cells in the bone marrow and pre- T cells in the thymus $(21,22)$ and an imbalance in $\mathrm{T}$ helper cytokine secretion by $\mathrm{PBMC}(10,23)$. A significant decrease in $\mathrm{Zn}++$ and $\mathrm{Se}++$ levels in whole blood has been reported in diabetic pregnancy $(24,25$, 26), compared to normoglycemic pregnancy. The potential beneficial effects of Zinc and Chromium have been reported in patients with type 2 diabetes mellitus (27-29).

The objective of the present study is to evaluate the relationship of concentrations of the trace elements and glycemic control with insulin and diet in GDM, and establish any correlation between the trace elements and lymphocyte sub-population in diabetic pregnancies. The Hypothesis of the study includes: (1) Correlations between use of diet or insulin for glycemic control women with GDM or Type 2 diabetes and serum levels of electrolytes, including $\mathrm{Zn++}, \mathrm{Cu}++, \mathrm{Se}++$, $\mathrm{Mg}++$ and $\mathrm{Cr}+++$, would suggest a role for these elements in the management of diabetes in pregnancy; (2) Correlation between the elements and $\mathrm{T}$ lymphocyte subset status, suggests an immunoregulatory role for the trace elements. This would open the gate to future innovative therapeutic intervention.

\section{Patients and methods}

\section{Subjects}

The study included 63 women with gestational diabetes (43 women controlled with diet and 20 women controlled with insulin) and 16 pregnant women with Type 2 diabetes (5 women controlled with diet and 15 women controlled with insulin), and, as the control, 44 normal pregnant women and 48 healthy non-pregnant women were included. The diet-treated versus insulin-treated groups were included to assess the severity 
of the diabetes and at the same time to afford the opportunity to assess the effect of treatment on the level of trace elements and the T lymphocyte subsets. In order to evaluate the effect of normal pregnancy on the level of the trace elements and the T lymphocytes subset status, a control group of 48 healthy, non-pregnant women and 44 normal pregnant women were included. They were matched for age and parity the diabetic study patients, none of whom had a history of diabetes, preeclampsia, hypertension or renal disease. All the patients had clinical evaluation confirmation of gestational diabetes, Type 2 diabetes and the allocation of patients, to dietary control or insulin, was according to the practice guidelines of the Hospital. About 10-15 ml of blood was drawn from each patient without the use of tourniquet, in the third trimester of pregnancy, for estimation of the trace elements and electrolytes and lymphocyte sub-populations. Gestational diabetes was diagnosed for the first time during pregnancy with a $75 \mathrm{~g}$ glucose tolerance test (GTT). Type 2 diabetics were those women who had pregestational diabetes that had started a few years before and had been on treatment before the onset of the current pregnancy. The dietcontrolled groups managed their diabetic condition solely through a diabetic diet. All women had a blood glucose profile to determine the insulin requirement. The insulin regimen included a combination of shortacting (Actrapid ${ }^{\circledast}$ and Monotard ${ }^{\oplus}$ ) morning and evening doses. Participation in this study was voluntary and conducted with the informed consent of all participants. Approval for the study was obtained from the Institutional Ethics for Safety of Human Subjects for Research.

\section{Lymphocyte analysis}

Five $\mathrm{ml}$ of peripheral venous blood was collected from each individual in EDTA tubes and analyzed for the percentage of immune activation-associated lymphocyte subsets within 4-6 hours following phlebotomy. Lymphocyte subpopulations analyzed for included CD4+ T helper cells expressing CD25, HLADR, CD54, CD45RA (naïve T cells), CD45RO (memory T cells), CD29 (Helper/inducer T cells); CD8+ cytotoxic $\mathrm{T}$ cells expressing CD25, HLADR or CD38; CD19+ B cells bearing the autoimmune-associated antigen CD5; and $\mathrm{T}$ cells expressing natural killer cell antigens: $\mathrm{CD} 3+\mathrm{CD} 16+\mathrm{CD} 56+$. Fifty $\mu \mathrm{l}$ of blood was incubated for $30 \mathrm{~min}$ at room temperature including death in utero, delayed organ maturation, high birth weight and many other abnormalities (10-12). The disorder is transitory, and insulin utilization and blood sugar levels may return to normal with 5 $\mu \mathrm{l}$ of flourescein-isothiocyanate (FITC) or phycoerythrin (RD1) conjugated monoclonal antibodies (mAb), to surface markers of interest. The cells were then treated with Q-prep (Coulter Corporation, Hialeah, FL, USA) for hemolysis, stabilization and amplification of the antigen-antibody reaction and fixation, with paraformaldehyde. A two-color fluorescence analysis using an automated flow cytometer (Coulter, Altra cell sorter, San Diego 92121, California, USA) was performed. Positive analysis regions for cells expressing specific surface antigens were set against isotypic controls and specific binding of fluorophore-conjugated monoclonal antibodies was analyzed by cytoflurograph according to standard methods recommended by the manufacturer. Monoclonal antibodies specific for human T-lymphocytes and subpopulations (CD3, CD4, CD8), B-lymphocytes (CD19) and lymphocyte activation (CD25, CD29, CD38, CD45RA, CD45RO, CD54, CD62, TCR-vB6, HLA-DR) were purchased from Dakopatts, A/S, Copenhagen, Denmark and from Immunotech, Coulter Corporation, Hialeah, FL, USA. 


\section{Trace element analysis}

Ten $\mathrm{ml}$ of venous blood was collected from each patient in metal-free tubes (BectonDickinson, New Jersey, USA), without any anticoagulant. Serum was separated and analyzed for trace metal content using graphite furnace atomic absorption. Briefly, $\mathrm{Cu}++$, $\mathrm{Zn++}, \mathrm{Se}++$ and $\mathrm{Cr}+++$ in the serum samples were measured with the use of an atomic absorption spectrophotometer (model 2380, Perkin-Elmer, Oak Brook, IL, USA) with a graphite furnace HGA 300 and analytical wavelengths of $324.8 \mathrm{~nm}$ for $\mathrm{Cu}++$, $213.8 \mathrm{~nm}$ for $\mathrm{Zn++}, 196.0 \mathrm{~nm}$ for Se++ and $357.9 \mathrm{~nm}$ for $\mathrm{Cr}+++$. Serum $\mathrm{Mg}++$ levels were measured in the same spectrophotometer, using an air-acetylene flame and one-slot burner equipped with a deuterium lamp and an analytical wavelength of 258.2 $\mathrm{nm}$. Duplicates of each measurement were made, with the use of both aqueous and serum quality controls. Results are reported as $\mu \mathrm{g} / \mathrm{L}$ of whole blood for $\mathrm{Zn++}, \mathrm{Cu}++, \mathrm{Se}++$ and $\mathrm{Mg++}$; and in $\mathrm{ng} / \mathrm{dl}$ for $\mathrm{Cr}+++$.

\section{Measurement of malondialdehyde}

Malondialdehyde (MDA) is a natural product formed in all mammalian cells as a product of lipid peroxidation. MDA is a highly reactive three carbon dialdehyde produced as a byproduct of polyunsaturated fatty acid peroxidation, it is a marker of oxidative stress, which is associated with hyperglycemia and insulin dysfunction. MDA readily combines with several functional groups on molecules including proteins, lipoproteins, and DNA. In the present study malondialdehyde was measured by a spectrophotometric method as previously (30-32).

\section{Statistical analysis}

All statistical analysis was performed using the SPSS for Windows statistical package (Norusis/SPSS, Inc.) version 17. Data on trace elements, electrolytes and malondialdehyde are presented as mean $\pm \mathrm{SD}$, while values of $\mathrm{T}$ cell lymphocytes subsets were presented as mean \% \pm SEM. Statistical analysis between two groups was performed using a two-tailed student t-test, comparisons involving multiple groups were performed with regression analysis. Pearson correlation was used to measure the association between variables. A value of $\mathrm{p}<0.05$ was considered statistically significant.

\section{Results}

\section{Lymphocyte sub-populations}

The differences in profiles of activated cellular phenotypes between non-pregnant subjects, healthy pregnant women, gestational diabetics treated with dieting and gestational diabetics treated with insulin are shown in Table 1. The following lymphocyte subsets were higher in healthy pregnant women compared to their non-pregnant counterparts; they included activated T-helper cells $(\mathrm{CD}+\mathrm{CD} 25) \quad(\mathrm{p}<0.01), \mathrm{CD} 4+$ HLA-DR+ $(\mathrm{p}<0.01)$, and CD8+HLA-DR+ $(\mathrm{p}<0.01)$. There were significant increases in $\mathrm{T}$ cells with NK markers, activated T-helpers cells $\mathrm{CD} 4+\mathrm{CD} 25+(\mathrm{p}<0.01)$ and CD4+HLA-DR+ $(\mathrm{p}<0.01)$, memory cells $\mathrm{CD} 4+\mathrm{CD} 45 \mathrm{RO}+$ and activated T-cytotoxic cells CD8+HLA$\mathrm{DR}(\mathrm{p}<0.01)$ in the insulin controlled GDM compared to the diet treated GDM and healthy pregnant women. Generally, there were much less activated cellular phenotypes in diet treated gestational diabetics compared to insulin treated GDM. However, while the frequency of CD4+HLA-DR+ and $\mathrm{CD} 45 \mathrm{RO}+\mathrm{CD} 45 \mathrm{RA}+$ cells was significantly elevated in the diet-treated Type 2 diabetes cohort $(\mathrm{p}<0.05)$, while CD4+ CD25+ were significantly elevated in the insulin treated cohort $(\mathrm{p}<0.05)$ relative to the non-pregnant cohort, no changes were observed compared to the normal pregnancy cohort. 
Table 1 Trace electrolyte concentrations in peripheral blood of non-pregnant control subjects, healthy pregnant women, and women with gestational diabetes being treated with dietary therapy alone or with insulin at $3^{\text {rd }}$ trimester of pregnancy

\begin{tabular}{|c|c|c|c|c|c|c|}
\hline $\begin{array}{l}\text { Serum } \\
\text { trace } \\
\text { element }\end{array}$ & $\begin{array}{l}\text { Non-pregnant } \\
\text { subjects } \\
(n=40)\end{array}$ & $\begin{array}{l}\text { Healthy } \\
\text { pregnant } \\
\text { subjects } \\
(\mathrm{n}=33)\end{array}$ & $\begin{array}{l}\text { Gestational diabetes } \\
\text { Dieting } \\
(n=26)\end{array}$ & $\begin{array}{l}\text { Gestational } \\
\text { diabetes } \\
\text { Insulin-treated } \\
(n=10)\end{array}$ & $\begin{array}{l}\text { Pregnant-Type } 2 \\
\text { diabetes } \\
\text { Dieting } \\
(n=5)\end{array}$ & $\begin{array}{l}\text { Pregnant-Type } \\
2 \text { diabetes } \\
\text { Insulin-treated } \\
(n=10)\end{array}$ \\
\hline $\mathrm{Zn}(\mu \mathrm{g} / \mathrm{l})$ & $788.4 \pm 30.2$ & $645.9 \pm 23.9^{* *}$ & $671.6 \pm 37.8^{*}$ & $664.5 \pm 46.5$ & $437.0 \pm 22.7^{* * ף}$ & $650.6 \pm 91.4$ \\
\hline $\mathrm{Cu}(\mu \mathrm{g} / \mathrm{l})$ & $1552.4 \pm 86.2$ & $2840 \pm 102.6^{* * *}$ & $2672.2 \pm 98.1$ *** & $3094.0 \pm 112.0^{* * *}$ & $3067.0 \pm 67.5^{* * *}$ & $2442.0 \pm 157.5^{* * *}$ \\
\hline $\mathrm{Mg}(\mu \mathrm{g} / \mathrm{l})$ & $15917.5 \pm 266.2$ & $13139.0 \pm 57.9^{* *}$ & $15987.5 \pm 288.0$ & $14400.0 \pm 50$ & $16000.0 \pm 110.79$ | & $16540.0 \pm 423.9$ \\
\hline $\mathrm{Cr}(\mathrm{ng} / \mathrm{dl})$ & $19.9 \pm 6.3$ & $24.2 \pm 6.9$ & $14.9 \pm 5.9$ & $6.0 \pm 6.0 * 9$ & $29.0 \pm 5.6$ & $6.6 \pm 32.49$ \\
\hline
\end{tabular}

${ }^{*} p<0.05,{ }^{* *} p<0.01$ and ${ }^{* * *} p<0.001$ relative to non-pregnant subjects, $\uparrow \mathrm{p}<0.05$ as compared to healthy pregnant subjects at $3^{\text {ed }}$ trimester, $\psi$ $\mathrm{p}<0.05$ as compared to healthy pregnant subjects at $2^{\text {nd }}$ trimester.

Table 2 Malondialdehyde levels in peripheral blood of non-pregnant control subjects, gestational diabetes patients and pregnant type 2 diabetes women at third trimester of pregnancy

\begin{tabular}{|c|c|c|c|c|c|c|}
\hline $\begin{array}{l}\text { Malondialdehyde } \\
\text { levels }\end{array}$ & $\begin{array}{l}\text { Non-pregnant } \\
\text { subjects } \\
(n=30)\end{array}$ & $\begin{array}{l}\text { Healthy } \\
\text { pregnant } \\
\text { subjects } \\
(n=31)\end{array}$ & $\begin{array}{l}\text { Gestational } \\
\text { diabetes } \\
\text { Dieting } \\
(\mathrm{n}=26)\end{array}$ & $\begin{array}{l}\text { Gestational } \\
\text { diabetes } \\
\text { Insulin-treated } \\
(n=10)\end{array}$ & $\begin{array}{l}\text { Women with } \\
\text { Type } 2 \text { diabetes } \\
\text { Dieting } \\
(n=5)\end{array}$ & $\begin{array}{l}\text { Pregnant women } \\
\text { with Type } 2 \\
\text { diabetes } \\
\text { Insulin-treated } \\
(n=10)\end{array}$ \\
\hline $\begin{array}{l}\text { Malondialdehyde } \\
(\mu \mathrm{mol} / \mathrm{L})\end{array}$ & $0.38 \pm 0.05$ & $0.535 \pm 0.18$ & $0.411 \pm 0.13$ & $0.385 \pm 0.27$ & $1.10 \pm 0.01 *$ * & $0.72 \pm 0.24^{*}$ \\
\hline
\end{tabular}

\section{Trace elements and diabetic pregnancy}

As shown in Table 2, serum $\mathrm{Zn}++$ levels were significantly lower in normal pregnancy as compared to non-pregnant women $(\mathrm{p}<0.01)$. No change in $\mathrm{Zn}++$ levels was observed in GDM cohorts. However, a significantly lower level was observed in the diet controlled Type 2 diabetes group compared to the healthy pregnant cohort $(\mathrm{p}<0.05)$. Conversely, $\mathrm{Cu}++$ levels were elevated in all the diabetic pregnant cohorts compared to non-pregnant women $(\mathrm{p}<0.001)$ with no significant difference between the diabetic cohorts. Apart from the lower levels of Se++ and $\mathrm{Mg}++$ in normal pregnancy compared to non-pregnant women $(\mathrm{p}<0.01)$ there were no other changes in the GD cohorts. Compared to healthy pregnancy, in Type 2 cohorts both diet-controlled and insulintreated showed a significant increase in $\mathrm{Se}++(\mathrm{p}<0.05)$ while only the insulin-treat- ed showed a significant increase in $\mathrm{Mg}++$. A significant decrease in $\mathrm{Cr}+++$ was observed in both the gestational diabetes and the Type 2 diabetes cohorts controlled with diet, compared to normal pregnancy $(\mathrm{p}<0.05)$.

\section{Correlations between immunophenotype of lymphocyte subpopulations and serum trace element concentration}

As shown in Table 3, in normal pregnancy, $\mathrm{Cu}++$ had a significant correlation with $\mathrm{CD} 4+\mathrm{CD} 25+; \mathrm{r}=0.388 \quad(\mathrm{p}<0.05)$ and $\mathrm{CD} 3+\mathrm{CD} 16+\mathrm{CD} 56+; \mathrm{r}=0.435(\mathrm{p}<0.01)$ but an inverse or negative correlation with naïve $\mathrm{T}$ cells $(\mathrm{CD} 4+\mathrm{CD} 45 \mathrm{RA}+) ; \mathrm{r}=-0.372(\mathrm{p}<0.05)$. There was a highly significant correlation between CD4+HLA-DR+ and Se++; $r=0.480$ $(\mathrm{p}<0.01)$ and with $\mathrm{Mg}++; \mathrm{r}=0.836(\mathrm{p}<0.01)$. Among the diet controlled GDM, $\mathrm{Cu}++$ had a highly negative correlation with $\mathrm{CD} 45 \mathrm{RO}+$ / CD45RA+; $r=-748 \quad(p<0.05) . \quad$ Conversely, 
$\mathrm{Zn++}$ and $\mathrm{Mg}++$ had a strong correlation with $\mathrm{CD} 45 \mathrm{RO}+/ \mathrm{CD} 45 \mathrm{RA}+$; $\mathrm{r}=0.625(\mathrm{p}<0.01)$ with $\mathrm{Zn}++$ and $\mathrm{r}=0.550(\mathrm{p}<0.05)$ with $\mathrm{Mg}++$. In the insulin treated GDM group, $\mathrm{Zn}++$ had a positive correlation with $\mathrm{CD} 4+\mathrm{CD} 29+$; $\mathrm{r}=$ $0.997(\mathrm{p}<0.05)$. There were changes in HLA$\mathrm{DR}+$ cells that correlated with serum trace element concentrations, with CD4+-HLA$\mathrm{DR}+$, but not CD8+HLA-DR+ increasing in direct proportion to serum $\mathrm{Mg}++(\mathrm{p}<0.05)$ and $\mathrm{Se}++(\mathrm{p}<0.01)$ in healthy pregnant and with $\mathrm{Mg}++$ in insulin-treated GD patients $(p<0.01)$. This may be a reflection of the role of these elements in regulation of lymphocyte activation.

The CD4+CD29+ cells (as a percentage of the total CD4+ population), were observed to decrease significantly from the second to third trimester in Type 2 diabetes treated with insulin $(\mathrm{p}<0.01)$. Interestingly, these cells exhibited an increase in percentage in association with serum $\mathrm{Mg++}$ in healthy, pregnant subjects; and to serum $\mathrm{Zn}++$ and serum Se++ in insulin-controlled GDM patients. Another significant finding was the association between $\mathrm{CD} 4+\mathrm{CD} 25+$ and trace elements. In Type 2 diabetic women treated with insulin, $\mathrm{Cr}+++$ had a strong correlation with CD4+CD25+; $r=0.906(\mathrm{p}<0.05)$.

\section{Analysis of the association between memory/naïve and trace elements}

There was an inverse correlation between percentage expression of $\mathrm{CD} 45 \mathrm{RO}+1$ CD45RA $+\mathrm{T}$ cells (reflecting immune activation) and serum $\mathrm{Cu}++$ within the GDM diet and GD insulin cohorts, which was not observed in the healthy cohort. On the other hand, $\mathrm{Zn}++$ correlated directly with this cell population in the diet controlled GDM cohort $(\mathrm{p}<0.01)$. A positive correlation between $\mathrm{Mg}++$ and $\mathrm{CD} 45 \mathrm{RO}+/ \mathrm{CD} 45 \mathrm{RA}+$ $\mathrm{T}$ cells was also observed in healthy pregnancy, diet- and insulin -controlled GDM cohorts $(\mathrm{p}<0.05)$.

Table 3 Frequencies of peripheral blood lymphocyte subpopulations in non-pregnant control subjects, healthy pregnant subjects, and women with gestational diabetes being treated with diet therapy or insulin

\begin{tabular}{|c|c|c|c|c|c|c|}
\hline $\begin{array}{l}\text { Lymphocyte } \\
\text { subpopulation }\end{array}$ & $\begin{array}{l}\text { Non- } \\
\text { pregnant } \\
\text { subjects } \\
(n=48)\end{array}$ & $\begin{array}{l}\text { Healthy } \\
\text { pregnant } \\
\text { subjects } \\
(n=44)\end{array}$ & $\begin{array}{l}\text { Gestational } \\
\text { diabetes } \\
\text { dieting } \\
(n=43)\end{array}$ & $\begin{array}{l}\text { Gestational } \\
\text { diabetes } \\
\text { insulin- } \\
\text { treated } \\
(\mathrm{n}=20)\end{array}$ & $\begin{array}{l}\text { Pregnant } \\
\text { Type } 2 \\
\text { diabetes } \\
\text { dieting } \\
(n=5)\end{array}$ & $\begin{array}{l}\text { Pregnant } \\
\text { Type } 2 \\
\text { diabetes } \\
\text { insulin- } \\
\text { treated } \\
(\mathrm{n}=11)\end{array}$ \\
\hline $\mathrm{CD} 3+\mathrm{CD} 16+\mathrm{CD} 56+a$ & $5.9 \pm 1.0$ & $6.4 \pm 1.5$ & $4.8 \pm 2.0$ & $10.3 \pm 2.8$ & $5.4 \pm 2.0$ & $8.7 \pm 2.8$ \\
\hline $\mathrm{CD} 4+\mathrm{CD} 25+b$ & $3.4 \pm 0.5$ & $6.5 \pm 0.9^{* *}$ & $10.6 \pm 2.1^{* *}$ & $13.5 \pm 3.9^{* * a}$ & $3.7 \pm 2.1$ & $14.4 \pm 6.3^{*}$ \\
\hline $\mathrm{CD} 4+\mathrm{HLA}-\mathrm{DR}+b$ & $4.0 \pm 0.4$ & $5.8 \pm 0.8^{*}$ & $5.5 \pm 0.8^{*}$ & $9.3 \pm 1.5^{* * \Pi \Psi}$ & $8.6 \pm 2.8^{*}$ & $11.5 \pm 4.6$ \\
\hline $\mathrm{CD} 4+\mathrm{CD} 45 \mathrm{RO}+b$ & $49.8 \pm 1.9$ & $48.9 \pm 1.8$ & $54.4 \pm 1.6^{* \pi}$ & $56.2 \pm 3.1^{* \pi}$ & $42.2 \pm 8.6$ & $53.7 \pm 3.6$ \\
\hline $\mathrm{CD} 4+\mathrm{CD} 45 \mathrm{RA}+b$ & $41.1 \pm 1.6$ & $46.9 \pm 2.4^{*}$ & $36.8 \pm 2.1^{* \pi}$ & $38.3 \pm 3.3^{* \pi}$ & $44.8 \pm 4.1$ & $43.3 \pm 5.7$ \\
\hline $\mathrm{CD} 4+\mathrm{CD} 29+b$ & $40.4 \pm 8.9$ & $44.5 \pm 3.4$ & 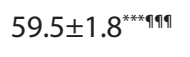 & $62.4 \pm 5.1^{* * * \text { ตा }}$ & $46.7 \pm 7.4$ & $44.9 \pm 6.5$ \\
\hline $\mathrm{CD} 8+\mathrm{CD} 25+d$ & $0.96 \pm 0.3$ & $1.8 \pm 0.6$ & $3.8 \pm 1.1^{* * \pi}$ & $2.8 \pm 1.2^{*}$ & $3.8 \pm 1.7$ & $4.7 \pm 2.3$ \\
\hline $\mathrm{CD} 8+\mathrm{HLA}-\mathrm{DR}+d$ & $7.9 \pm 1.3$ & $17.4 \pm 3.1^{* *}$ & $10.7 \pm 1.8^{* \pi}$ & $12.7 \pm 2.5^{*}$ & $10.7 \pm 2.8$ & $16.2 \pm 5.5$ \\
\hline CD45RO+/CD45RA+ & $4.5 \pm 1.2$ & $7.1 \pm 3.8$ & $8.2 \pm 1.8^{*}$ & $4.6 \pm 1.3$ & $11.2 \pm 3.2^{*}$ & $6.5 \pm 2.0$ \\
\hline
\end{tabular}

Values (mean \% \pm SEM) are given as percentage of lymphocytes in each major lymphocyte population (CD3, CD4, and CD8). ainCD3+, bin CD4+, cin CD8+. Pregnant women compared to non-pregnant controls, ${ }^{*} p<0.05,{ }^{* *} p<0.01,{ }^{* * *} p<0.001$. Pregnant women with diabetes compared to healthy pregnant subjects, $" p<0.05, " 1 p<0.01$, ${ }^{\text {"1 } p ~} p<0.001$. Diet-treated GD patients compared to insulin treated GD ${ }^{\Psi} p<0.05$. 
Table 4 Correlations between immunophenotype of lymphocyte subpopulations and serum trace element concentrations in peripheral blood of healthy pregnant women, gestational diabetes patients and pregnant Type 2 diabetes women at third trimester of pregnancy

\begin{tabular}{lll}
\hline Trace element & Immunopheno-type & Correlation coefficient \\
\hline $\mathrm{NP}$ & $\mathrm{CD} 4+\mathrm{CD} 25+$ & $0.388^{*}$ \\
$\mathrm{Cu}$ & $\mathrm{CD} 4+\mathrm{CD} 45 \mathrm{RA}+$ & $-0.372^{*}$ \\
$\mathrm{Cu}$ & $\mathrm{CD} 3+\mathrm{CD} 16+\mathrm{CD} 56+$ & $0.435^{* *}$ \\
$\mathrm{Cu}$ & $\mathrm{CD} 4+-\mathrm{HLA}-\mathrm{DR}+$ & $0.480^{* *}$ \\
$\mathrm{Se}$ & $\mathrm{CD} 4+-\mathrm{HLA}-\mathrm{DR}+$ & $0.836^{* *}$ \\
$\mathrm{Mg}$ & & \\
\hline $\mathrm{GD}$ (Diet-controlled) & $\mathrm{CD} 45 \mathrm{RO}+/ \mathrm{CD} 45 \mathrm{RA}+$ & $-0.748^{* *}$ \\
\hline $\mathrm{Cu}$ & $\mathrm{CD} 45 \mathrm{RO}+/ \mathrm{CD} 45 \mathrm{RA}+$ & $0.625^{* *}$ \\
$\mathrm{Zn}$ & $\mathrm{CD}+\mathrm{CD} 25+$ & $0.632^{*}$ \\
$\mathrm{Mg}$ & $\mathrm{CD} 45 \mathrm{RO}+/ \mathrm{CD} 45 \mathrm{RA}+$ & $0.550^{*}$ \\
$\mathrm{Mg}$ & & \\
\hline $\mathrm{GD}$ (Insulin-treated) & $\mathrm{CD} 4+\mathrm{CD} 29+$ & $0.997^{*}$ \\
\hline $\mathrm{Zn}$ & & \\
\hline Pregnant with Type 2 diabetes (Insulin-treated) & $\mathrm{CD} 4+\mathrm{CD} 25+$ & $0.906^{*}$ \\
\hline $\mathrm{Cr}$ &
\end{tabular}

Immunophenotypic values are listed as percentage of total peripheral blood lymphocyte population (mean percent \pm SEM). Mean values for trace element $\mathrm{s} \pm \mathrm{SEM}$ are listed in $\mathrm{ug} / \mathrm{I}$ for $\mathrm{Zn}, \mathrm{Cu}$, se and $\mathrm{Mg}$, and in $\mathrm{ng} / \mathrm{l}$ for $\mathrm{Cr}$. Pearson correlation was used to measure the association between with significance of each correlation assessed using Student's 2 -tailed t-test. * Correlation is significant at the 0.05 level (2-tailed). ${ }^{* *}$ Correlation is significant at the 0.01 .

\section{Oxidative stress and immune regulation}

An inverse correlation of MDA with CD4+CD25+ cells was observed in the present study. Conversely, MDA activity was observed to increase in direct proportion to $\mathrm{CD} 45 \mathrm{RO}+$ memory $\mathrm{T}$ cells in the blood of women with diet-controlled GDM $(\mathrm{p}<0.05)$, and in inverse proportion to memory cells in diet-treated women afflicted with Type 2 diabetes $(p<0.05)$, a possible role of MDA in immune regulation needs further investigation. Malondialdehyde activity showed an inverse correlation with CD4+HLA-DR+ $(\mathrm{p}<0.01)$ cells in insulin-treated GDM patients but not CD8+HLA-DR+. CD8+CD25+ cells frequency varied directly with MDA in healthy pregnant women $(\mathrm{p}<0.05)$ as shown in Table 4 . An inverse correlation was observed between MDA concentration and CD8+CD25+ in insulin controlled Type 2 diabetes- in the third trimester.

\section{Discussion}

\section{Lymphocyte activation}

The percentage of CD4+CD25+ (presumed suppressor-inducer cells) was higher in blood of GDM versus healthy pregnant subjects, which was not observed in blood of Type 2 diabetes-afflicted cohorts (Table 1). A subset of T-helper $(\mathrm{CD} 4+)$ cells expressing IL-2R have been shown to constitute a population of "professional" suppressor T cells (T-reg cells) that prevent induction of organ-specific autoimmune disease (33). Our finding that these cells are elevated in GDM versus healthy pregnant subjects may be an 
indication of the occurrence of a protective mechanism mounted by the host immune system in response to some fundamental element of GDM pathogenesis. This study also revealed the expansion of CD4+HLA$\mathrm{DR}+$ and CD8+HLA-DR+ activated T cells in diabetic pregnancy which exceeds those in healthy controls. Our observation that naïve T cells, CD4+CD45RA+ (which may act as suppressors of immune activation (34) were present at lower frequencies in GDM blood with a concomitant increase in the percentage of memory T cells, CD4+CD45RO+ (which increase in immune activation) than in healthy pregnant women (Table 1) was expected. An increase in naïve $T$ cells during late pregnancy suggests a protective role. The lack of increase in this population in the blood of GDM- or Type 2 diabetes-afflicted women indicates an increase in immune activation versus immunosuppression during late pregnancy in diabetic patients and may in turn correlate with a greater risk to the pregnancy.

A higher number of CD4+CD29+ (presumed helper/inducer cells) activated T cell subpopulations were also observed in GDM patients than in the blood of women experiencing a normal pregnancy, and a previous investigation showed this population to be down-regulated in normal pregnancy (35). These observations suggest that maternal immunosuppression, which is normally increased during pregnancy to compensate for the immunostimulatory activity of paternal antigens, may not be as effective in GDM patients as in healthy women. However this subpopulation was not observed to vary significantly from healthy control values in the peripheral blood of Type 2 diabetic women (Table 1). These cells are a T-helper/ inducer subset, observed to be increased in the peripheral blood of patients with $\mathrm{T}$ cellmediated diseases, such as Guillain-Barre syndrome (36). Their activity may or may not contribute to the pathogenesis of GDM, however, their increased frequency in pa- tients may indicate a decreased capacity to control pregnancy-induced immune activation. The fact that changes in activated lymphocyte sub-population were not observed in Type 2-diabetic women is an indicator of differences in the immunopathogenesis of GDM versus Type 2 diabetes.

\section{Mechanisms of immune modulation in type 2 and gestational diabetes mellitus: Trace elements and oxidative stress in immune regulation}

The effect of diabetes in pregnancy may arise through two related mechanisms, namely, the direct effect of trace elements and oxidative stress on immune regulation. A significant decrease in $\mathrm{Zn++}$ was shown in the diet-treated diabetic group relative to healthy pregnancy $(\mathrm{p}<0.05)$ (Table 2$)$, which supports the hypothesis that $\mathrm{Zn}++$ and $\mathrm{Cu}++$ may play a role in the mechanisms regulating the immune response $(30,31)$. A significant increase in $\mathrm{Cu}++$ was observed in all pregnant cohorts relative to nonpregnant women $\mathrm{p}<0.01$ ), but not compared with the diabetic groups. In previous work we demonstrated a strong positive correlation between serum $\mathrm{Cu}++$ and the size of $\mathrm{T}$ cell $(\mathrm{CD} 3+)$ populations expressing the NK markers CD16 and/ or CD56 in Kuwaiti women with normal pregnancy (31). Also in the present study we found that serum $\mathrm{Cu}++$ increased in direct proportion to the percentage of CD4+CD25+ T cells (Treg cells) in healthy pregnant subjects $(\mathrm{p}<0.05)$ and in GDM patients treated with diet $(\mathrm{p}<0.01)$ (Table 3). Hence, increase of serum $\mathrm{Cu}++$ may be a normal response in late pregnancy. These findings support the hypothesis that $\mathrm{Zn}++$ and $\mathrm{Cu}++$ may play a role in the mechanisms regulating the immune response (23). Mg++ was significantly higher in the Type 2 diet treated cohort relative to healthy women $(\mathrm{p}<0.01)$ (Table 2$)$. It is of interest to note that $\mathrm{CD} 4+\mathrm{CD} 29+$ cells exhibited an in- 
crease in percentage proportional to serum $\mathrm{Mg}++$ in healthy, pregnant subjects; and to serum $\mathrm{Zn++}$ and serum Se++ in insulintreated GDM patients (Table 3). Similarly, CD4+-HLA-DR+, but not CD8+HLA-DR+, was increased in direct proportion to serum $\mathrm{Mg}++(\mathrm{p}<0.05)$ and $\mathrm{Se}++(\mathrm{p}<0.01)$ in healthy pregnant and with $\mathrm{Mg}++$ in insulintreated GDM patients $(\mathrm{p}<0.01)$ (Table 3$)$. $\mathrm{Mg}++$ ions have been reported to specifically inhibit the antigen-presenting capacity of human epidermal Langerhans cells, which was associated with a reduced expression of HLA-DR by these cells (37). Another study found that deficiency of $\mathrm{Mg}++$ is associated with immunosuppression in athletes, suggesting that $\mathrm{Mg}++$ has a role in immunoregulation $(38,39)$, which is consistent with our findings in this study. Furthermore, an inverse correlation was noted between percentage expression of CD45RO+/ CD45RA+ $\mathrm{T}$ cells (reflecting immune activation) and serum $\mathrm{Cu}++$ within the GDMM diet and GD insulin cohorts, which was not observed in the healthy cohort (Table 3). On the other hand, $\mathrm{Zn}++$ correlated directly with this cell population in the GDM diet cohort $(\mathrm{p}<0.01)$. These results reflect the role of these elements in regulation of lymphocyte activation.

Relative to subjects with normal pregnancy, $\mathrm{Cr}+++$ levels were observed in this study to be significantly decreased in GD and Type 2 women treated with insulin (Table 2). These results suggest that this element also contributes at some level to the pathogenesis of GD and pregnancy in diabetes. This is consistent with the role of this metal as a regulator of carbohydrate metabolism in pregnancy (40). Serum Cr+++ was observed to vary in direct proportion to CD4+CD25+ $\mathrm{T}$ cells in the blood of insulin-treated Type 2 diabetes patients $(\mathrm{p}<0.05)$ (Table 3$)$ suggesting that $\mathrm{Cr}+++$ may also be involved in immune regulatory mechanisms.

Oxidative stress is an immunological hallmark of type 1 diabetes, therefore the in- verse correlation of MDA with CD4+CD25+ cells observed in the present study, may suggest the involvement of some immunoregulatory mechanisms. This suggests that increased levels of MDA in some subjects of this group may be associated with apoptotic deletion of activated $\mathrm{T}$ cells expressing HLA-DR, but the same was not observed in healthy pregnant subjects. Although no statistically significant difference was observed in serum $\mathrm{Se}++$ between GDM women and the healthy pregnant cohort, in type 2 diabetes, a significant increase in serum $\mathrm{Se}++$ relative to healthy pregnancy was observed $(\mathrm{p}<0.05) . \mathrm{Se}++$ is an active oxygen species scavenger (41) as well as being an integral part of the antioxidant enzyme glutathione peroxidase. Normal gestation induces an increase of lipid peroxidation products, and this process is substantially increased in diabetes. An inverse correlation was observed between MDA concentration and this population in Type 2 diabetic women treated with insulin in the third trimester however, which suggests a possible apoptotic deletion of $\mathrm{CD} 8+\mathrm{CD} 25+$ activated population in some of the Type 2 diabetes women treated with insulin, which may be induced by reactive oxygen species, as was described previously $(42,43)$.

\section{Conclusion}

In conclusion, this study also revealed the expansion of memory $\mathrm{T}$ cells CD4+CD45RO, CD4+HLA-DR+ and CD8+HLA-DR+ activated $\mathrm{T}$ cells in diabetic pregnancy and lower frequencies of naïve $\mathrm{T}$ cells, CD4+CD45RA+, which act as suppressors of immune activation. An increase in naïve $\mathrm{T}$ cells during late pregnancy suggests a protective role. The present study has suggested two mechanisms through which diabetes in pregnancy causes adverse immunoregulation of T. lymphocytes. The results of the present study reflect the role of deficiencies 
of trace elements $\mathrm{Zn++}, \mathrm{Se}++, \mathrm{Cu}++$ in regulation of lymphocyte activation. Secondly, in this study, increased lipid peroxidation products, measured as malondialdehyde concentration, were increased in diabetes in pregnancy. Oxidative stress may cause apoptotic deletion of $\mathrm{CD} 8+\mathrm{CD} 25+$ activated population in diabetic women in pregnancy. Dietary manipulation of antioxidant status with $\mathrm{Zn++}, \mathrm{Se++}, \mathrm{Cu}++, \mathrm{Mg}++$ and $\mathrm{Cr}++$ may therefore allow substantial improvements to be made in existing approaches to management of diabetes in pregnancy.

Acknowledgment: This work was sponsored by $\mathrm{Ku}-$ wait University grant MRO2/00.

Authors' contributions: Conception and design: FM, $\mathrm{HA}, \mathrm{AO}$; Acquisition of data: FM, AO, AD and WA; Analysis of data: FM; Interpretation of data: FM, $\mathrm{HA}$ and AO; Drafting the article: FM, HA, AO.

Conflict of interest: The authors declare that they have no conflict of interest. This article was not sponsored by any external organisation.

\section{References}

1. Damm P. Gestational diabetes mellitus and subsequent development of overt diabetes mellitus. Dan Med Bull. 1998;45(5):495-509.

2. Buchanan TA, Xiang AH. Gestational diabetes mellitus. J Clin Invest. 2005;115:485-91.

3. Chu SY, Callaghan WM, Kim SY, Schmid CH, Lau J, England LJ, et al. Maternal Obesity and risk of Gestational Diabetes Mellitus. Diabetes Care. 2007;30:2070-6.

4. Zhang C, Ning Y. Effect of dietary and lifestyle factors on the risk of gestational diabetes: review of epidemiologic evidence. Am J Clin Nutr. 2011;94:S1975-9.

5. Ben-Haroush A, Yogev Y, Hod M. Epidemiology of Gestational Diabetes Mellitus and its association with Type 2 Diabetes. Diabet Med. 2004;21:103-13

6. Yogev Y, Visser G. Obesity, gestational diabetes and pregnancy outcome. Seminars in Fetal and Neonatal Medicine. 2009;14(2):77-84.

7. Correa A, Gilboa SM, Besser LM, Botto LD, Moore CA, Hobbs CA, et al. Diabetes mellitus and birth defects. Am J Obst Gynecol. 2008;199:2371-8.

8. Solomon CG, Seely EW. Brief review: hypertension in pregnancy: a manifestation of the insulin resistance syndrome? Hypertension. 2001;37(2):232-9.
9. Tamas G, Kerenyi Z. Gestational diabetes: current aspects on athogenesis and treatment. Exp Clin Endocrinol Diabetes. 2001;109(Suppl 2):S400-11.

10. Lupo VR, Stys SJ. Recurrence of gestational diabetes in subsequent pregnancies. In: Weiss PM, Coustan DR, editors. Gestational Diabetes. Vienna, Austria: Springer-Verlag; 1988. p. 123-6.

11. Rice GE, Illanes SE, Mitchell MD. Gestational diabetes mellitus: a positive predictor of type 2 diabetes? Int J Endocrinol. 2012;2012:721653.

12. Evans JL, Goldfine ID, Maddux BA, Grodsky GM. Are Oxidative Stress-Activated Signaling Pathways Mediators of Insulin Resistance and B-Cell Dysfunction? Diabetes. 2003;52:1-8.

13. Paolisso G, Giugliano D. Oxidative stress and Insulin action. Is there a relationship? Diabetologia. 1996;39:357-63.

14. West IC. Radicals and Oxidative stress in diabetes. Diabet Med. 2000;17:171-80.

15. Georgiou HM, Lappas M, Georgiou GM, Marita A, Bryant VJ, , Hiscock R, et al. Screening for biomarkers predictive of gestational diabetes mellitus. Acta Diabetol. 2008;45:157-65.

16. Kuhnertm M, Strohmeier R, Stegm Yller M, et al. Changes in lymphocyte subsets during normal pregnancy. Eur J Obstet Gynecol Reprod Biol. 1998;76:147-51.

17. Liu CL, Xu HY, Liu Y. Serum level of soluble interleukin-2 receptor and $\mathrm{T}$ lymphocyte subpopulations in normal pregnancy. Chung Hua Fu Chan Ko Tsa Chih. 1994;29:518-20.

18. Vanderbeeken YE, Duchateau J, Gregoire M, Vandermeersch B, Collet H, Lucas A. Modulation of $B$ cell stimulation by maternal serum. Immunol Invest. 1991;20(3):287-304.

19. Watanabe M, Iwatani Y, Kaneda T, Hidaka Y, Mitsuda N, Morimoto Y, et al. Changes in T, B, and NK lymphocyte subsets during and after normal pregnancy. Am J Reprod Immunol. 1997;37:368-77.

20. Chandra RK. Nutrition and Immunology: From the clinic to cellular biology and back again. Proc Nutr Soc. 1999;58:681-3.

21. Xiang AH, Peters RK, Trigo E. Multiple metabolic defects during late pregnancy in women at high risk for type 2 diabetes. Diabetes. 1999;48:848-54.

22. Fraker PJ, King LE. Programming. Annu Rev Nutr. 2004;24:277-98.

23. Beck FW, Prasad AS, Kaplan J, Fitzgerald JT, Brewer GT. Changes in cytokines production and T cell sub-population in experimentally induced zinc deficient human. Am J Physiol. 1997;272:E1002-7.

24. Wang Y, Tan M, Huang Z, Sheng L, Ge Y. Elemental Contents In Serum Of Pregnant Women With 
Gestational Diabetes Mellitus. Biological Trace Element Research. 2002;88:113-8.

25. Borella P, Szilagyi A, Than G, Csaba I, Giardino A, Facchinetti F. Maternal plasma concentration of magnesium, calcium, zinc and copper in normal and pathological pregnancies. Science of the Total Environment. 1990;99(1-2):67-76.

26. Huijgen A, Sanders G. Intracellular and extracellular, ionized and total $\mathrm{Mg}++$ in pre-eclampsia and uncomplicated pregnancy. Clinical Chemistry and Laboratory Medicine. 1999;37:55-9.

27. Anderson RA, Roussel AM, Zouari N, Mahjoub S, Matheau JM, Kerkeni A. Potential Antioxidant Effects of Zinc and Chromium Supplementation in People with Type 2 Diabetes Mellitus. J Am Coll Nutr. 2001;20:212-18.

28. Roussel AM, Kerkeni A, Zouari N, Mahjoub S, Matheau JM, Anderson RA. Antioxidant Effects of Zinc Supplementation in Tunisian s with Type 2 Diabetes Mellitus. J Am Coll Nutr. 2003;22:316-21.

29. Ryan GJ, Wanko NS, Redman AR, Cook CB. Chromium as Adjunctive Treatment for Type 2 Diabetes. Ann Pharmacother. 2003;37:876-85.

30. Abul HT, Mahmoud FF, El-Rayes SK, Haines DD, Omu A. Potential aetiological involvement of $\mathrm{Zn++}, \mathrm{Cu}++, \mathrm{Se}++$ and $\mathrm{Mg}++$ in pre-eclamptic and hypertensive parturient women in Kuwait. Trace Elements and Electrolytes. 2001;18(1):20-5.

31. Abul H, Mahmoud F, Haines D, Mannazhath N. Pregnancy-Associated Relationships Between Serum Content of $\mathrm{Cu} 2+, \mathrm{Mg} 2+, \mathrm{Zn} 2+, \mathrm{Se} 2+$ and Peripheral Blood Lymphocyte Sub-populations in Kuwaiti Women. Trace Elements and Electrolytes. 2004;21(3):168-73.

32. Jentzsch AM, Bachmann H, Furts P, Biesalski HK. Improved analysis of malondialdehyde in human body fluids. Free Radical Biology and Medicine. 1996;20(2):251-6.

33. Thornton A, Shevach E. Suppressor effector function of CD4+CD25+ immunoregulatory T cells is antigen nonspecific. J Immunol. 2000;164:183-90.

34. Clement LT. Isoforms of the CD45 common leukocyte antigen family: markers for human T-cell differentiation. J Clin Immunol. 1992;12:1-10.
35. Matthiesen L, Berg G, Ernerudh J, Hakansson L. Lymphocyte subsets and mitogen stimulation of blood lymphocytes in normal pregnancy. Am J Reprod Immunol. 1996;35:70-9.

36. Sindern E, Oreja-Guevara C, Raulf-Heimsoth M, Baur X, Malin JP. A longitudinal study of circulating lymphocyte subsets in the peripheral blood during the acute stage of Guillain-Barre syndrome. J Neurol Sci. 1997;151:29-34.

37. Schempp CM, Dittmar HC, Hummler D, SimonHaarhaus B, Schulte-Mönting J, Schöpf E, et al. Magnesium ions inhibit the antigen-presenting function of human epidermal Langerhans cells in vivo and in vitro. Involvement of ATPase, HLADR, B7 molecules, and cytokines. J Invest Dermatol. 2000;115(4):680-6.

38. Nielsen FH, Lukaski HC. Update on the relationship between magnesium and exercise. Magnes Res. 2006 Sep;19(3):180-9.

39. König D, Weinstock C, Keul J, Northoff H, Berg A. Zinc, iron, and magnesium status in athletes-influence on the regulation of exercise-induced stress and immune function. Exerc Immunol Rev. 1998;4:2-21.

40. Sharma S, Agrawal RP, Choudhary M, Jain S, Goyal $S$, Agarwal V. Beneficial effect of chromium supplementation on glucose, $\mathrm{HbA1C}$ and lipid variables in individuals with newly onset type-2 diabetes. J Trace Elem Med Biol. 2011;25(3):149-53.

41. Xu H, Liu Q, Zhou J, Zuo P, Wang J. The mechanism for the effect of Se++ supplementation on immunity. Biol Trace Elem Res. 1995;48(3):231-8.

42. Agostini M, Di Marco B, Nocentini G, Delfino DV. Oxidative stress and apoptosis in immune diseases. Int J Immunopathol Pharmacol. 2002;15(3):157-64.

43. Hildeman DA, Mitchell T, Teague TK, Henson P, Day BJ, Kappler J, et al. Reactive oxygen species regulate activation-induced $\mathrm{T}$ cell apoptosis. Immunity. 1999;10(6):735-44. 